\title{
Nutritional value and fatty acid composition of some traditional Argentinean meat sausages
}

\author{
Composição nutricional e perfil de ácidos graxos de embutidos tradicionais da Argentina
}

\author{
Mara Cristina ROMERO ${ }^{1}$, Ana María ROMERO ${ }^{1}$, Mirtha Marina DOVAL ${ }^{1}$, Maria Alicia JUDIS ${ }^{1 \star}$
}

\begin{abstract}
The aim of this study was to determine the nutritional composition (moisture, protein, carbohydrates, and total fat) of some meat products produced in the northeastern Argentina, analyzing fatty acids composition, polyunsaturated/saturated fatty acid ratio PUFA/SFA ratio (polyunsaturated/ saturated fatty acids), n-6/n-3 ratio, and CLA (conjugated linoleic acid) content. Thirty traditional meat products produced by different processes were used. The samples were classified into 4 different categories as follows: salamín (dry cured and fermented sausage), chorizos (raw sausage), chorizo ahumado (cooked and smoked sausage), and morcilla (cooked sausage). From the results obtained it can be said that the total carbohydrate contents of the salamín studied were slightly lower; fat content of raw chorizo was significantly lower, and protein content of chorizo ahumado was significantly higher than those comparison from databases from other regions of Argentina, USA, and Spain. Except for chorizo, which has a value lower than 0.4, the PUFA/SFA-stearic ratio of the other products were a little higher than those reported by other researchers. CLA (Conjugated linoleic acid) contents between $0.03 \%$ and $0.19 \%$ were detected. The results obtained indicate that salamín produced in northeastern Argentina, Chaco state, shows high protein and PUFA (Polyunsaturated fatty acids) contents, and low atherogenic and thrombogenic indexes, which makes it a more healthful product than those of similar composition produced in other countries.

Keywords: PUFA/SFA ratio; chorizo; salamin; $n 6 / n 3$ ratio; morcilla.
\end{abstract}

\section{Resumo}

O objetivo deste trabalho foi determinar a composição nutricional de alguns produtos de carne elaborados no nordeste da Argentina, a análise da composição dos ácidos graxos, conteúdo de CLA, relações AGPI/AGS e n-6/n-3. Trinta produtos tradicionais de carne a partir de processos diferentes foram utilizados. As amostras foram classificadas em 4 categorias: Salamin (embutido seco e fermentado), chorizo (linguiça), chorizo ahumado (linguiça defumada) e morcilla (morcilha preta). A partir dos resultados obtidos, por comparação com bancos de dados de outras regiões da Argentina, EUA e Espanha, observa-se que o conteúdo de hidratos de carbono do Salamin foi ligeiramente inferior; a gordura do chorizo fresco foi significativamente menor; e a proteína do chorizo ahumado foi significativamente maior. Com exceção do chorizo, que teve um valor menor, de 0,4, as relações AGPI/AGS-esteárico do resto dos produtos foram um pouco superiores às reportadas por outros pesquisadores. Conteúdos de 0,03\% a 0,19\% de CLA foram detectados. Os resultados sugerem que o Salamin feito no Estado do Chaco, localizado no nordeste da Argentina, por seu maior conteúdo de proteínas e ácidos graxos poli-insaturados e menores índices de aterogênico e trombogênico, é um produto mais saudável que os produtos equivalentes de outros países do mundo.

Palavras-chave: relação AGPI/AGS; chorizo; salamin; relação n-6/n-3; morcilla.

\section{Introduction}

The most representative Argentinian traditional sausages are: "Chorizo" (raw sausage), "Morcilla" (cooked sausage), "Chorizo ahumado" (cooked and smoked sausage), and "Salamin" (dry cured and fermented sausage). These products have different manufacturing processes depending on the regions. The basic ingredients of meat products (ARGENTINA, 2010) are beef, pork, bacon (fat), salt, additives, and spices that give the sausage its characteristic flavor (Table 1).

The manufacturing of traditional products is not standardized and are generally monitored subjectively without strict control of the characteristics required for these products, for instance casing size, processing parameters, such as temperature, relative humidity, and airflow rates, and smoking conditions (FERNÁNDEZ-FERNÁNDEZ; VÁZQUEZODÉRIZ; ROMERO-RODRÍGUEZ, 2002). However, if hygienic conditions and the intrinsic properties of foods are maintained, the traditional sausages could be considered safe products (PANAGOU; NYCHAS; SOFOS, 2013).

These meat products are sold at butcher shops and supermarkets, where they can be found packaged in polyethylene film or in vacuum sealed pouches.

Recent studies on Argentina eating habits show that the majority of its population consumes between a quarter and onehalf kilogram of sausages once a week. (ARGENTINA, 2006).

Received 11/5/2011

Accepted 10/12/2012 (005250)

${ }^{1}$ Laboratorio de Industrias Alimentarias II, Universidad Nacional del Chaco Austral, Cte Fernandez 755, Roque Saenz Peña, CP 3700, Chaco, Argentina,

e-mail: judis@uncaus.edu.ar

${ }^{*}$ Corresponding author

DOI: http://dx.doi.org/10.1590/S0101-20612013005000007 
Table 1. Basic composition and process of traditional meat products.

\begin{tabular}{ll}
\hline \multicolumn{1}{c}{ Products } & \multicolumn{1}{c}{ Ingredients and process involved in its elaboration } \\
\hline Salamín (dry cured and fermented sausage). & $\begin{array}{l}\text { Beef, Pork or mixture of them, with the addition of bacon, salt, sodium nitrite, sugar, spices, } \\
\text { and wine. Subjected to a ripening process in temperature and air relative humidity controlled } \\
\text { chambers. } \\
\text { Beef, Pork or mixture of them, with the addition of bacon and several additives. Put into animal } \\
\text { gut or other similar containers authorized for that purpose. }\end{array}$ \\
Chorizo (raw sausage). & $\begin{array}{l}\text { Prepared with blood of animals permitted for consumption; collected during slaughter carried } \\
\text { out under sanitary conditions and in properly washed containers; defibrinated and filtered, with } \\
\text { or without bacon, chopped pork leather, salt, nitrite, spices, and other previously authorized } \\
\text { substances. The product is subjected to a cooking process. } \\
\text { Pork and beef, with or without bacon, sugar, salt, nitrite, starch products, milk powder, and } \\
\text { spices. The mixture is stuffed into tripe casings approved for this purpose. The product is } \\
\text { subjected to a cooking smoking process. }\end{array}$ \\
$\begin{array}{l}\text { Chorizo ahumado (cooked and smoked sausage). } \\
\text { Similar to mortadella a bologna-type cooked meat } \\
\text { sausage, but different casing type. }\end{array}$ &
\end{tabular}

From the nutritional point of view, meat products are an important source of proteins of high biological value (BERIAIN; CHASCO; LIZASO, 2000); however it is internationally accepted that these sausages present some negative aspects as a consequence of their high animal fat content. The relatively high cholesterol level and low polyunsaturated/saturated fatty acid ratio (PUFA/SFA) are risk factors for some disorders such as coronary diseases (MUGUERZA et al., 2001).

Argentine meat has been traditionally produced from natural and pasture-based farming. Meat produced from grainbased or pasture-based farming differs in antioxidant, prooxidant, and fatty acid composition. Pasture-fed cattle renders meat with a higher $n-3$ polyunsaturated fatty acids (PUFA) and conjugated linoleic acid (CLA) content than their counterparts fed concentrate diets (LATIMORI et al., 2008).

Accordingly, the nutritional value and fatty acid composition of Argentinian meat products could be different from meat products produced in other places in the world; therefore, the aim of this study was to determine the nutritional composition (moisture, protein, carbohydrates, and total fat) of meat products produced in three representative areas of Chaco state, northeastern Argentina, analyzing the fatty acids composition, PUFA/SFA ratio, $n-6 / n-3$ ratio, CLA content, and Atherogenicity (AI) and Thrombogenicity (TI) Indexes.

\section{Materials and methods}

\subsection{Samples}

Thirty traditional meat products produced by different processes were used. The samples were classified into 4 different categories as follows: salamín (dry cured and fermented sausage), 7 samples; chorizos (raw sausage), 8 samples; chorizo ahumado (cooked and smoked sausage), 6 samples; and morcilla (cooked sausage), 9 samples. They were obtained from three areas in Chaco state (east, center, and west), triplicated or duplicated according to the availability of local factories, kept in properly labeled disposable containers at low temperatures, and taken to the laboratory, where they were frozen at $-20{ }^{\circ} \mathrm{C}$ until analysis.

\subsection{Chemical composition and nutritional value}

Moisture, protein, and total fat were analyzed according to AOAC International (ASSOCIATION..., 1990) methods. Total carbohydrates were quantified using antrone Clegg's methods (1956), expressed as glucose percentage, using a UV-Vis Beckman DU 640B (Fullerton, CA) spectrophotometer; and $\mathrm{pH}$ was measured with a 525A ORION pH meter (Boston, MA) equipped with a glass electrode. Total energy was calculated according to the Mercosur Technical Regulation on Nutrition labeling of packaged foods (MONTEVIDEO, 2003).

\subsection{Fatty acids composition}

Total lipids were extracted using the Bligh and Dyer (1959) method. Fatty acid composition was determined after methylation using an Agilent (model 6850A HP, Agilent Technologies Inc, CA, USA) gas chromatography with a Supelco 2340 capillary column of $60 \mathrm{~m}$ and $0.25 \mathrm{~mm}$ internal diameter according to AOAC No 969.33 (ASSOCIATION..., 1990).

The temperature of the injector and detector was kept at $250{ }^{\circ} \mathrm{C}$. The injected volume was $1.0 \mu \mathrm{l}$. The carrier gas was helium at $0.6 \mathrm{psi}$. The Split ratio used was 1:100. The temperature of the column was kept at $140^{\circ} \mathrm{C}$ for 5 minutes, raised to $240^{\circ} \mathrm{C}$ at $4{ }^{\circ} \mathrm{C} / \mathrm{min}$, and maintained at $240^{\circ} \mathrm{C}$ for 20 minutes. Fatty acids were identified by comparison of their retention times with those of authentic standards (Supelco 37 Components FAME Mixture, Bellefonte, PA) and reported as percentage of the total fatty acids determined. Results were expressed as saturated (SFA), monounsaturated (MUFA), and polyunsaturated fatty acids (PUFA); and the PUFA/SFA-Stearic and MUFA+PUFA/SFAStearic ratios, Atherogenicity (AI) and Thrombogenicity (TI) Indexes were calculated as proposed by Ulbricht and Southgate (1991) (Equations 1 and 2):

$$
\begin{aligned}
& A I=(C 12: 0+4 x C 14: 0+C 16: 0) / \\
& {\left[\left(\sum M U F A+\sum P U F A(n-6)+(n-3)\right)\right]} \\
& T I=(C 14: 0+C 16: 0+C 18: 0) /\left[0.5 x \sum M U F A+0.5 x \sum P U F A\right. \\
& \left.(n-6)+3 x \sum P U F A(n-3)+(n-3) /(n-6)\right]
\end{aligned}
$$




\subsection{Statistical analysis}

All analyses were performed in duplicate. The data were recorded as mean \pm standard deviation and analyzed using the Statgraphics Plus for Windows 4.0 software package. The analysis of variance (ANOVA) was carried out to test for any significant differences at $(\mathrm{p}<0.05)$ between the factors and the Least Significant Difference of Fisher was used to identify significant differences between means.

\section{Results and discussion}

\subsection{Chemical composition}

Chemical composition, $\mathrm{pH}$, and energy values of the meat products studied are shown in Table 2. Many differences were found in the composition of the four types of sausage, which shows the diversity of the ingredients used and the different processing according to the manufacturing area. Furthermore, the variation found in the nutrient content in each type of product could be attributed to the different formulations used by each manufacturer because the CAA is rather vague in terms of ingredients and amounts that must be added to make these products (corrected sentence). For example, chorizo ahumado can be prepared with different proportions of bacon, thus affecting the fat content in the final product, while the variation in the carbohydrate content of fresh pork sausage can be attributed to the presence or absence of sugar, used in some cases to enhance color development.

The salamín, whose elaboration process includes a ripening and drying, showed the highest $(\mathrm{p}<0.05)$ protein, fat and energy content and the lowest $(\mathrm{p}<0.05)$ moisture and $\mathrm{pH}$ values. These results agree with those reported for this type of product (LORENZO et al., 2000).

The proximate composition of northeastern Argentinian salamín was similar to that of other dry-cured sausages published in food composition tables in Argentine, USA, and Spain (SARA, 2008; UNITED..., 2002; UNIVERSIDAD..., 2009); its carbohydrates content, however, was slightly lower.

Although the elaboration process of products investigated is different, the content of water, protein, fat, and carbohydrates did not differ $(\mathrm{p}<0.05)$ significantly between the chorizos (raw sausage) and morcilla (cooked sausage). However, morcilla $\mathrm{pH}$ value was higher than chorizo $(\mathrm{p}<0.05)$, probably due to the high concentration of protein blood used as ingredient.

In comparison with other sources, such as SARA, USDA and DIAL, the fat content of similar products are significantly higher (44.2 g/100 g; $30.7 \mathrm{~g} / 100 \mathrm{~g}$ and $29.3 \mathrm{~g} / 100 \mathrm{~g}$, respectively) than that of chorizo produced in this region. Such behavior was also observed when morcilla data were compared with those reported by SARA and USDA databases; on the other hand, fat content was the same as that reported by DIAL.

The moisture content of both products (morcilla and chorizo) analyzed was higher than those reported by the above mentioned chemical composition table of foods although the water content for morcilla was similar to that from DIAL. The protein levels of raw chorizo were lower than those reported by USDA (19.2 g/100 g) and DIAL (21.18 g/100 g), and similar to that from SARA $(13.0 \mathrm{~g} / 100 \mathrm{~g})$, while the protein content for morcilla was higher than that reported by DIAL $(6.87 \mathrm{~g} / 100 \mathrm{~g})$, similar to that from SARA $(14.6 \mathrm{~g} / 100 \mathrm{~g})$. Moreover, the carbohydrate content of chorizo was to that from SARA $(1.1 \mathrm{~g} / 100 \mathrm{~g})$, higher than that from USDA (tr) and lower than that of DIAL $(1.9 \mathrm{~g} / 100 \mathrm{~g})$. With regard to the morcilla cooked sausage, its carbohydrate content was similar to that from SARA $(1.29 \mathrm{~g} / 100 \mathrm{~g})$, and significantly lower than that from DIAL (16.7 g/100 g).

Chorizo ahumado, which has intermediate moisture, had the highest total carbohydrate content $(2 \mathrm{~g} / 100 \mathrm{~g})$, which could be related to the fact that starch is added to increase retention water capacity during cooking.

Since there is no data available on Chorizo ahumado, a comparison study was carried out between the composition of this product and mortadela (a formulation similar to chorizo ahumado but with different size and casing type) obtained from the food composition tables previously mentioned. The moisture content of the products analyzed was lower than those reported by SARA and DIAL (62.7 g/100 g and $60.5 \mathrm{~g} / 100 \mathrm{~g}$, respectively), but similar to that reported by USDA (54.0 g/100 g). Protein content was higher than all others $(12.7 \mathrm{~g} / 100 \mathrm{~g} ; 12.28 \mathrm{~g} / 100 \mathrm{~g}$, and $11.87 \mathrm{~g} / 100 \mathrm{~g}$ - SARA, USDA, and DIAL, respectively), while fat and carbohydrates contents were similar to those reported by other databases.

Table 2. Nutritional composition, energy values, and $\mathrm{pH}$ of the sausages analyzed: salamín, chorizo, morcilla, and chorizo ahumado. Contents are expressed in $\mathrm{g} / 100$ of edible portion.

\begin{tabular}{|c|c|c|c|c|}
\hline & $\begin{array}{c}\text { Salamín } \\
\begin{array}{c}(\text { dry cured sausage })^{1} \\
\mathrm{n}=7\end{array}\end{array}$ & $\begin{array}{c}\text { Chorizo } \\
{\text { (raw sausage })^{1}}^{\mathrm{n}=8}\end{array}$ & $\begin{array}{c}\text { Morcilla } \\
\text { (cooked sausage })^{1} \\
n=9\end{array}$ & $\begin{array}{c}\text { Chorizo ahumado } \\
\begin{array}{c}\text { (smoked sausage })^{1} \\
n=6\end{array}\end{array}$ \\
\hline Moisture & $34.85 \pm 6.31^{\mathrm{a}}$ & $59.60 \pm 3.64^{\mathrm{b}}$ & $58.54 \pm 4.47^{\mathrm{b}}$ & $50.25 \pm 8.25^{c}$ \\
\hline Protein & $26.59 \pm 5.57^{\mathrm{a}}$ & $15.09 \pm 2.70^{\mathrm{b}}$ & $18.43 \pm 4.14^{\mathrm{bc}}$ & $21.33 \pm 6.30^{\mathrm{ac}}$ \\
\hline Total fat & $29.71 \pm 11.11^{\mathrm{a}}$ & $17.70 \pm 7.09^{\mathrm{b}}$ & $17.65 \pm 4.12^{\mathrm{b}}$ & $18.50 \pm 10.35^{\mathrm{b}}$ \\
\hline Total carbohydrates & $0.63 \pm 0.43^{\mathrm{a}}$ & $0.67 \pm 0.72^{\mathrm{a}}$ & $0.92 \pm 0.49^{\mathrm{a}}$ & $2.33 \pm 1.29^{\mathrm{b}}$ \\
\hline Energy value* & $1575.84 \pm 481.83^{\mathrm{a}}$ & $930.70 \pm 232.83^{\mathrm{b}}$ & $989.24 \pm 182.75^{\mathrm{b}}$ & $1093.47 \pm 341.42^{\mathrm{b}}$ \\
\hline $\mathrm{pH}$ & $5.44 \pm 0.34^{\mathrm{a}}$ & $6.18 \pm 0.21^{\mathrm{b}}$ & $6.50 \pm 0.13^{c}$ & $6.15 \pm 0.25^{b}$ \\
\hline
\end{tabular}

${ }^{1}$ Data presented as means \pm S.D. of samples, each one in duplicate. ${ }^{a}$ Different letters in the same line with indicate significant differences $(p<0.05)$. ${ }^{*}$ Calculation based $37.7 \mathrm{KJ} / \mathrm{g}$ $(9.0 \mathrm{cal} / \mathrm{g})$ for fat, $16.8 \mathrm{KJ} / \mathrm{g}(4.0 \mathrm{Kcal} / \mathrm{g})$ for protein and $16.8 \mathrm{KJ} / \mathrm{g}(4.0 \mathrm{Kcal} / \mathrm{g})$ for total carbohydrates. 
As seen from the results, in comparison with databases from other regions of Argentina, USA, and Spain, the total carbohydrate contents of the salamín studied were slightly lower; fat content of raw chorizo was significantly lower, and protein content of chorizo ahumado was significantly higher. However, the morcilla showed less fat content than similar products from other Argentine regions and much less carbohydrates than the same product produced in Spain.

\subsection{Determination of fatty acids composition}

Table 3 shows the fatty acid composition of meat sausages produced in the northeastern Argentina. The lipidic profile did not show significant differences between the four kinds of products analyzed $(\mathrm{p}<0.05)$. Monounsaturated fatty acids were the major constituents found ranging from $44 \%$ for salamín to $48 \%$ for morcilla. Oleic acid (18:1) was found in high amounts, ranging from $40 \%$ for chorizo to $43 \%$ for morcilla, respectively. Palmitic acid (16:0) was the major saturated fatty acid found, ranging of $22-26 \%$ for salamín and chorizo, respectively, followed by stearic acid (18:0), myristic acid (14:0), and butyric acid (4:0), which together accounted for $39 \%$ to $46 \%$ of total fatty acids in the products mentioned above.
Salamín had the highest n-6 polyunsaturated fatty acids concentration (14\%), while the chorizo showed the lowest (8\%). Small amounts of alpha linolenic acid (18:3n-3) were found in all sausages types. In the salamín, this fatty acid was found in a high concentration (2\%). The linoleic acid content varied from $8 \%$ to $14 \%$ in all products analyzed.

Despite the high amount of pork meat and bacon used in sausage manufacturing, which have a very limited amount of CLA (ZHANG et al., 2010), between $0.03 \%$ and $0.19 \%$ of CLA content was found in the meat products studied, although these values were lower than those reported for beef meat (DESCALZO; SANCHO, 2008) produced from grass-fed cattle.

Therefore, with respect to fatty acid composition, it can be concluded that the regional meat products show a similar MUFA content to that reported in the literature Muguerza et al. (2001), Campos et al. (2007), RUBIO et al. (2007) and Del Nobile et al. (2009), (42\%; $51 \%$; $44 \%$ and $47 \%$, respectively), and that the same behavior was observed for PUFA and SFA contents.

The PUFA/SFA ratio is one of the major parameters currently used to assess the nutritional quality of the lipid fraction of foods. Nutritional guidelines recommend a PUFA/ SFA ratio above 0.4 (WORLD..., 2003) although several researchers reported that this ratio must be considered together

Table 3. Fatty acid composition of salamín, chorizo, morcilla, and chorizo ahumado (\% of total fatty acids).

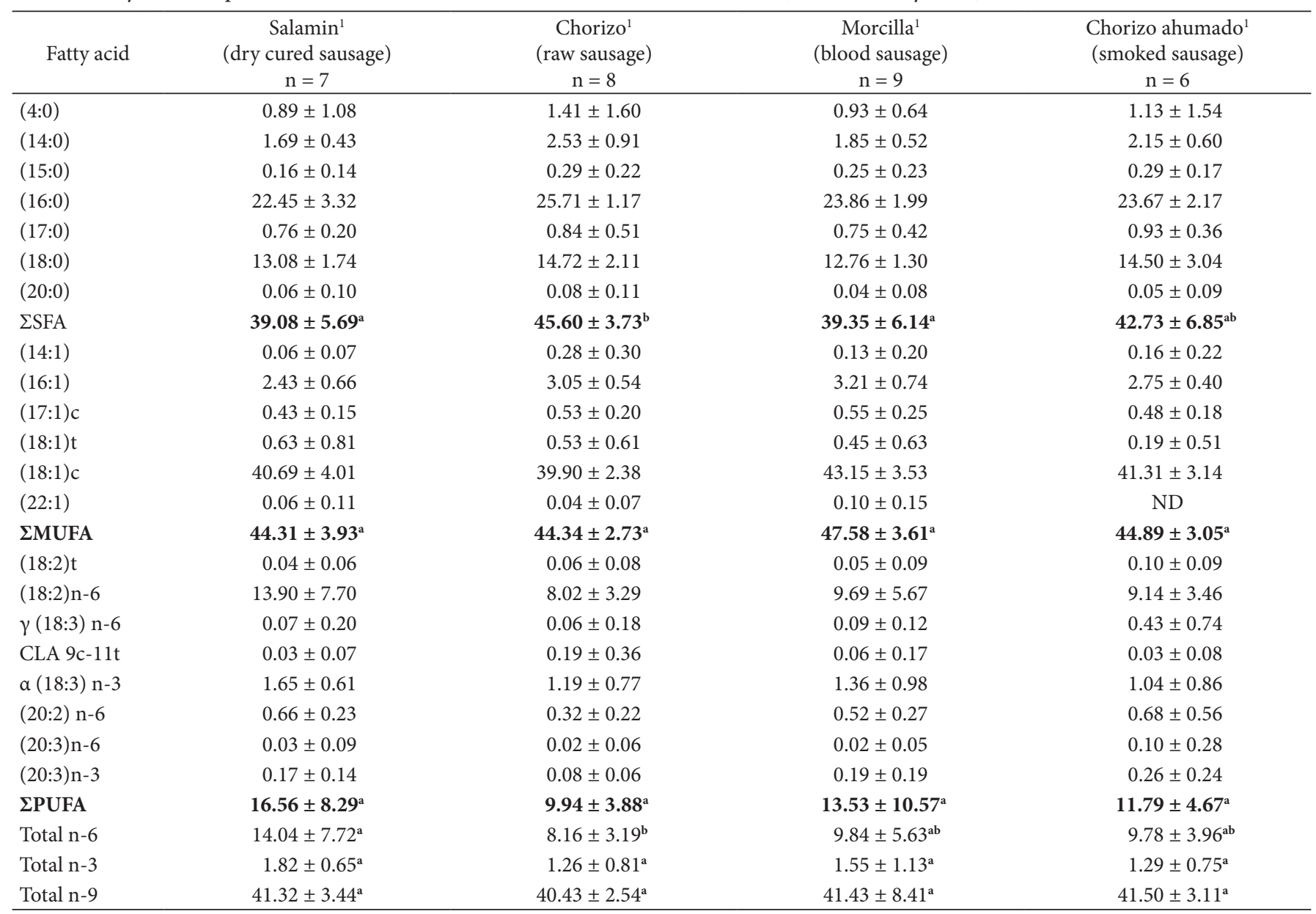

${ }^{1}$ Data presented as means \pm S.D. of samples, each one in duplicate. a, b, c Different letters in the same line with indicate significant differences $(p<0.05)$. 
Romero et al.

Table 4. Nutritionally significant ratios of salamín, chorizo, morcilla, and chorizo ahumado.

\begin{tabular}{|c|c|c|c|c|}
\hline Fatty acid & $\begin{array}{c}\text { Salamin }^{1} \\
\text { (dry cured sausage) } \\
\mathrm{n}=7\end{array}$ & $\begin{array}{c}\text { Chorizo }^{1} \\
\text { (raw sausage) } \\
n=8\end{array}$ & $\begin{array}{c}\text { Morcilla }^{1} \\
\text { (blood sausage) } \\
\mathrm{n}=9\end{array}$ & $\begin{array}{c}\text { Chorizo ahumado }{ }^{1} \\
\text { (smoked sausage) } \\
n=6\end{array}$ \\
\hline PUFA/SFA & $0.46 \pm 0.31^{\mathrm{a}}$ & $0.22 \pm 0.09^{a}$ & $0.35 \pm 0.46^{\mathrm{a}}$ & $0.30 \pm 0.16^{\mathrm{a}}$ \\
\hline$n-6 / n-3$ & $8.07 \pm 4.05^{\mathrm{ab}}$ & $4.19 \pm 2.65^{\mathrm{a}}$ & $5.90 \pm 3.86^{\mathrm{ab}}$ & $10.55 \pm 9.41^{\mathrm{b}}$ \\
\hline PUFA/SFA-Stearic & $0.70 \pm 0.51^{\mathrm{a}}$ & $0.33 \pm 0.14^{\mathrm{a}}$ & $0.53 \pm 0.50^{\mathrm{a}}$ & $0.44 \pm 0.23^{\mathrm{a}}$ \\
\hline MUFA+PUFA/SFA-Stearic & $2.44 \pm 0.76^{\mathrm{b}}$ & $1.77 \pm 0.22^{\mathrm{a}}$ & $2.25 \pm 0.56^{\mathrm{ab}}$ & $2.07 \pm 0.52^{\mathrm{ab}}$ \\
\hline Atherogenic Index & $0.50 \pm 0.11^{\mathrm{a}}$ & $0.67 \pm 0.13^{\mathrm{b}}$ & $0.53 \pm 0.05^{\mathrm{a}}$ & $0.58 \pm 0.14^{\mathrm{ab}}$ \\
\hline Thrombogenic Index & $1.09 \pm 0.25^{\mathrm{a}}$ & $1.45 \pm 0.31^{\mathrm{b}}$ & $1.17 \pm 0.22^{\mathrm{a}}$ & $1.30 \pm 0.30^{\mathrm{ab}}$ \\
\hline
\end{tabular}

${ }^{1}$ Data presented as means \pm S.D. of samples, each one in duplicate. ${ }^{a}$ Value in the same line with different letters have significant differences $(p<0.05)$.

with PUFA n-6/n-3 ratio due to the beneficial effect of linoleic acid (n-6) on health that is produced only when PUFA/SFA ratio is no greater than 1.5 .

SFA are considered to raise plasma cholesterol, except for stearic acid which reduces total and LDL cholesterol; therefore, the content of this fatty acid (stearic) is subtracted from the SFA fraction when the association between food saturated fatty acids and risk of heart diseases is studied. Moreover, MUFA have hypocholesterolemic effect, but they do not decrease HDL cholesterol, which protects against cardiovascular diseases. Therefore, PUFA/SFA-stearic ratio and MUFA+PUFA/ SFAstearic ratio were calculated for these products and they are shown in Table 4.

The ratio PUFA/SFA-stearic showed no significant differences between the products $(p>0.05)$, and they were similar to those reported by other researchers, such as traditional Spanish fermented sausage: 0.43 (MUGUERZA et al., 2001), Brazilian salami: 0.44 (CAMPOS et al., 2007), Spanish salchichón: 0.49 (RUBIO et al., 2007), and Italian salami 0.50 (DEL NOBILE et al., 2009).

MUFA+PUFA/SFA-stearic ratio showed significant differences between salamín and chorizo; salamín was the product with the highest value (2.44) showing that it has a better nutritional composition.

The values obtained for the other products analyzed were similar to those reported by Muguerza et al. (2001), Campos et al. (2007), RUBIO et al. (2007), and Del Nobile et al. (2009), who found 2.08, 2.07, 2.44 and 2.26, respectively.

Scientific evidence suggests that a very high PUFA n-6/n-3 ratio promotes the pathogenesis of many diseases, including cardiovascular disease (CVD), cancer, and inflammatory and autoimmune diseases, whereas an increased level of n-3 PUFA (a low n-6/n-3 PUFA ratio) exerts suppressive effects (SIMOPOULOS, 2008). Accordingly, the recommended n-6/ n3 PUFA ratio should not exceed 4.

The sausage products studied have $n-6 / n-3$ ratios higher than those suggested by international health organizations, which is agreement with Jimenez-Colmenero (2007), who reported that data from studies on meat products show that n-3 PUFAs is present in very low levels, generally less than $0.15 \mathrm{~g} / 100 \mathrm{~g}$; hence, they contribute little in terms of dietary recommendations.

The $n-6 / n-3$ ratio values of products investigated showed significant differences between chorizo ahumado and chorizo; all ratios were lower than those reported in the literature: 25.8 for cooked pork sausage (BAGGIO; BRAGAGNOLO, 2006), 12.4 for fermented pork sausage (RUBIO et al., 2007), and 12.22 for typical Italian salami (DEL NOBILE et al., 2009).

There is evidence that the type of fat is more important than the total amount of fat in the quantification of cardiovascular diseases risk; therefore, the Atherogenicity Index (AI) and the Thrombogenicity Index (TI) were also evaluated. The results obtained in this research showed that salamin had lower values of both indexes than those of chorizo $(\mathrm{p}<0.05)$. If comparing this values with those reported in the literature, it was possible to observe that they were much lower than that found for Spanish chorizo de Pamplona (MUGUERZA et al., 2001) and similar to those reported by Rubio et al. (2007), Campos et al. (2007) and Del Nobile et al. (2009).

\section{Conclusions}

From the data obtained in this study, it can be concluded that the salamín produced in northeastern Argentina, Chaco state, shows high protein and PUFA contents, and low atherogenic and thrombogenic indexes, which makes it a more healthful product than similar products produced in other countries. However, the other products analyzed (chorizos, morcilla, and chorizo ahumado) show a similar composition to that reported in the databases used.

\section{References}

ARGENTinA. Código Alimentario Argentino-CAA. Ley 18.284 18/07/69. Decreto 2126/71 - Ley de Regulación 18.284. Alimentos cárneos y afines. Buenos Aires, 2010. Disponível em: $<$ http://www.anmat.gov.ar/codigoa/CAPITULOVI.pdf $>$. Acesso em: 14 ago. 2012.

ARGENTINA. Convenio Universidad Nacional del Nordeste-Instituto Nacional de Tecnología Agropecuaria. UNNE-INTA. Convenio de Cooperación Técnica Facultad de Ciencias Económicas - Centro Regional Chaco Formosa - Ministerio de la Producción del Chaco: Comportamientos de Compra de Productos y Subproductos del Cerdo. Resistencia, 2006. Disponível em: <http://revistacyt. unne.edu.ar/imagenes/Comportamiento\%20de\%20compras\%20 porcinos\%20-\%20Informe\%20Preliminar.pdf>. Acesso em: 15 set. 2009.

ARGENTINA. Dirección Nacional de Salud Materno Infantil. Sistema de Análisis y Registro de Alimentos- SARA. versión 1.2.12. Buenos Aires: Ministerio de Salud, Presidencia de la Nación, 2008. Disponível em: <http://www.msal.gov.ar/htm/Site/promin/ 
UCMISALUD/archivos/htm/descarga-sara.htm>. Acesso em: 15 mar. 2009.

ASSOCIATION OF OFFICIAL ANALYTICAL CHEMISTS - AOAC. Official methods of analysis. 15th ed. Arlington: AOAC, 1990.

BAGGIO, S. R.; BRAGAGNOLO, N. The effect of heat treatment on the cholesterol oxides, chloresterol, total lipid and fatty acid contents of processed meat products. Food Chemistry, v. 95, p. 611-619, 2006. http://dx.doi.org/10.1016/j.foodchem.2005.01.037

BERIAIN, M. J.; CHASCO, J.; LIZASO, G. Relationship between biochemical and sensory quality characteristics of different commercial brands of Salchichón. Food Control, v. 11, p. 231-237, 2000. http://dx.doi.org/10.1016/S0956-7135(99)00104-8

BLIGH, E. G.; DYER, W. J. A rapid method of total lipid extraction and purification. Canadian Journal of Biochemistry and Physiology, v. 37, p. 911-917, 1959. http://dx.doi.org/10.1139/o59-099

CAMPOS, R.M. L. et al. Fatty acids and volatile compounds from salami manufactured with yerba mate (Ilex paraguariensis) extract and pork back fat and meat from pigs fed on diets with partial replacement of maize with rice bran. Food Chemistry, v. 103, p. 1159-1167, 2007. http://dx.doi.org/10.1016/j.foodchem.2006.10.018

CLEGG, K. M. The application of the anthrone reagent to the estimation of starch in cereals. Journal of Science Food Agricultural, v. 3, p. 40-44, 1956. http://dx.doi.org/10.1002/jsfa.2740070108

DEL NOBILE, M. A. et al. New strategies for reducing the pork backfat content in typical Italian salami. Meat Science, v. 81, p. $263-$ 269, 2009. http://dx.doi.org/10.1016/j.meatsci.2008.07.026

DESCALZO, A. M.; SANCHO, A. M. A review of natural antioxidants and theirs effects on oxidative status, odor and quality of fresh beef produced in Argentina. Meat Science, v. 79, p. 423-426, 2008.

FERNÁNDEZ-FERNÁNDEZ, E.; VÁZQUEZ-ODÉRIZ, M. L.; ROMERO-RODRÍGUEZ, M. A. Effects of manufacturing process variables on the physicochemical and sensory characteristics of Galician chorizo sausage. Journal of Science of Food and Agriculture, v. 82, p. 273-279, 2002. http://dx.doi.org/10.1002/ jsfa. 1023

JIMENEZ-COLMENERO, F. Healthier lipid formulation approaches in meat-based functional foods. Technological options for replacement of meat fats by non-meat fats. Trends in Food Science and Technology, v. 18, p. 567-578, 2007. http://dx.doi.org/10.1016/j. tifs.2007.05.006

LATIMORI, N. J. et al. Diet and genotype effects on the quality index of beef produced in the Argentine Pampeana region. Meat Science, v. 79, p. 463-469, 2008. http://dx.doi.org/10.1016/j. meatsci.2007.10.008

LORENZO, J. M. et al. Biochemical characteristics of two Spanish traditional dry-cured sausage varieties: Androlla and Botillo.
Journal of Food Composition and Analysis, v. 13, p. 809-817, 2000. http://dx.doi.org/10.1006/jfca.2000.0927

MONTEVIDEO. MERCOSUR/GMC/RES. n 46/03, del 10 de diciembre de 2003. Reglamento Técnico Mercosur sobre el Rotulado Nutricional de Alimentos Envasados. LII GMC - Grupo Mercado Común. Montevideo, 2003. Disponível em: <http://www. temasactuales.org/laws_policies/legislation_MERCOSUR.html>. Acesso em: 15 jun. 2009.

MUGUERZA, E. et al. Effect of replacing pork backfat with preemulsified olive oil on lipid fraction and sensory quality of Chorizo de Pamplona - a traditional Spanish fermented sausage. Meat Science, v. 59, p. 251-258, 2001. http://dx.doi.org/10.1016/S03091740(01)00075-4

PANAGOU, E. Z.; NYCHAS, G. E.; SOFOS, J., N. Types of traditional Greek foods and their safety. Food Control, v. 29, p. 32-41, 2013. http://dx.doi.org/10.1016/j.foodcont.2012.05.050

RUBIO, B. et al. Study of the self life of dry fermented sausage "salchichon" made from raw material enriched in monounsaturated and polyunsaturated fatty acids and stored under modified atmospheres. Meat Science, v. 76, p. 128-137, 2007. http://dx.doi. org/10.1016/j.meatsci.2006.10.021

SIMOPOULOS, A. P. The importance of the omega-6/omega-3 fatty acid ratio in cardiovascular disease and other chronic diseases. Experimental Biology and Medicine, v. 233, p. 674-688, 2008. http://dx.doi.org/10.3181/0711-MR-311

ULBRICHT, T. L. V.; SOUTHGATE, D. A. T. Coronary heart-disease- 7 dietary factors. Lancet, v. 338, p. 985-992, 1991. http://dx.doi. org/10.1016/0140-6736(91)91846-M

UNITED STATES DEPARTMENT OF AGRICULTURE - USDA. Agricultural Research Service, Nutrient Data Laboratory. In: GEBHARDT, S. E.; THOMAS, R. G. Nutritive Value of Foods. Beltsville: U. S. Department of Agriculture, 2002. Disponível em: $<$ http://www.nal.usda.gov/fnic/foodcomp/Data/HG72/hg72_2002. pdf> Acesso em: 15 mar. 2009.

UNIVERSIDAD COMPLUTENSE DE MADRID. DIAL Programa Departamento de Nutrición y Bromatología I. Programa de uso general para valoración de Dietas y cálculos de Alimentación. Madrid, 2009. Disponível em: <http://www.seh-lelha.org/ busalimento.aspx>. Acesso em: 15 mar. 2009.

WORLD HEALTH ORGANIZATION - WHO. WHO Technical Report Series, no. 916 (TRS 916). Diet, nutrition and the prevention of chronic diseases. Geneva, 2003. p. 87-88. Available from: <http://whqlibdoc.who.int/trs/WHO_TRS_916.pdf >.

ZHANG, W. et al. Improving functional value of meat products. Meat Science, v. 86, p. 15-31, 2010. http://dx.doi.org/10.1016/j. meatsci.2010.04.018 